\title{
Primary Production in the Northwestern Pacific Ocean*
}

\author{
Yatsuka SAIJo** and Shun-ei ICHIMURA***
}

\begin{abstract}
The primary production in the northwestern Pacific waters was measured during the cruises in August 1957 and in May, July August 1958. The standing crop of phytoplankton was measured on the basis of its chlorophyll content, and the photosynthetic rate of phytoplankton was determined by the ${ }^{14} \mathrm{C}$ method.

The average chlorophyll value in euphotic layers was found within the range from 0.4 to $0.7 \mathrm{mg} . / \mathrm{cu}$. m. for the Oyashio area and from 0.1 to $0.2 \mathrm{mg}$. $/ \mathrm{cu} . \mathrm{m}$. for the Kuroshio, except for the coastal water. Furthermore, it was observed in euphotic layers that a linear relationship exists between transparency of water and average chlorophyll content. The photosynthetic capacity of water taken from various depth of the sea was measured under an optimal light condition and at temperature of water in situ. On evaluation of photosynthetic capacity, the Oyashio area gave values $1-4 \mathrm{mg} . \mathrm{C} / \mathrm{cu} . \mathrm{m} . / \mathrm{hr}$., and the Kuroshio area from $0.1-0.7$ mg. C/cu. m./hr., respectively. The production was estimated by means of the tank and chlorophyll methods. The calculated value of the daily production rate was $0.2-0.4 \mathrm{~g} . \mathrm{C} / \mathrm{sq} . \mathrm{m}$. /day for the Oyashio area as well as the littoral region of the Kuroshio, and 0.05-0.1 g.C/ sq.m./day for the pelagic area of the latter.
\end{abstract}

As one of the most important clues to clarify the structure of plant community, recent attention of ecologists points to the production of organic matters through photosynthesis. The ecological problems in relation to growth, succession, geographical distribution and other phenomena of the plant community should be explained on the basis of the organic matter production. The quantitative knowledge of the causal relationships prevailing between the photosynthesis and environmental factors, no doubt, an indespensable background for agriculture, forestry and fishery. On the other hand, studies on the primary production have also attained an increasing interest in the field of geochemistry in pursuing the trait of carbon cycle on the earth.

From these points of view, the primary production in the ocean has been studied extensively in the last decade, and much important information has been accumulated. Especially, the ${ }^{14} \mathrm{C}$ tracer technique introduced by Steemann Nielsen has made it possible to disclose the productivity even in the pelagic

* Received June 22, 1960.

** Water Research Laboratory, Faculty of Science, Nagoya University.

*** Botanical Institute, Faculty of Science, Tokyo University of Education. area of the ocean.

The measurement of the primary production in the Pacific Ocean has been made by several investigators as SteemanN Nielsen (1957), Doty and OgurI (1956-1958), Jitts and Rotschi (1958) and Holmes et al. (1957, 1958), in the middle and tropical Pacific, and by Sorokin (1958) and MiYAKe (1958) in the northwestern Pacific area. However, the information is still insufficient for our understanding of the general feature of the primary production in the Pacific Ocean.

The present authors, therefore, made several researches on the primary production in the northwestern Pacific Ocean. The present report deals with results obtained during the cruises in summer 1957 and 1958.

\section{Methods}

Two cruises were made during August 118, 1957 and May 1-9, 1958 in the southern area off Honshu as far as lat. $30^{\circ} \mathrm{N}$. and the other was made during July 25-September 17, 1958 in the northeastern sea off Honshu Japan, covering the area from lat. $30^{\circ} \mathrm{N}$. to $55^{\circ} \mathrm{N}$. and from lon. $140^{\circ} \mathrm{E}$ to $170^{\circ} \mathrm{E}$. (Fig. 1).

The methods used were similar in principle to those described by SteemanN NiELSEN (1957), and Ryther and Yentsch (1957). The 
sampling of sea water was made from depths of 0,30 and 50 meters, and sometimes even from 10,20 , and 100 meters beneath the level.

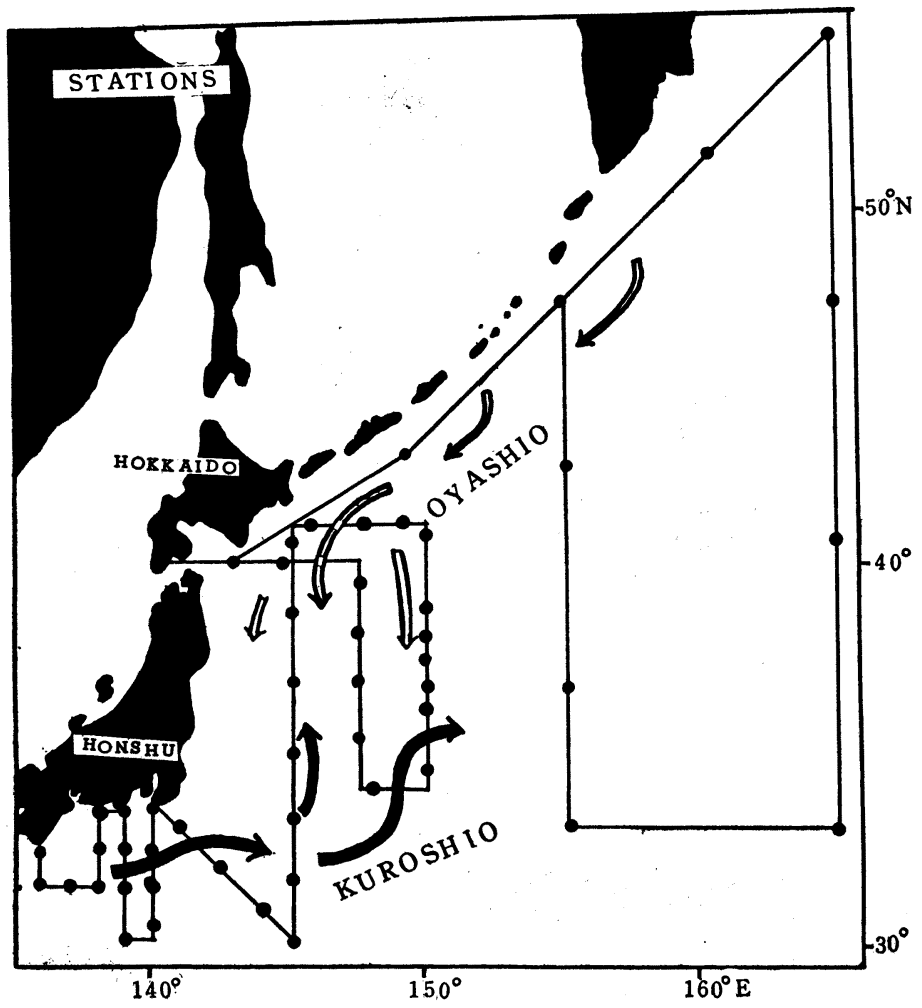

Fig. 1. A map showing the stations of chlorophyll measurement. daily production of organic matter was estimated by tank method as well as chlorophyll method.

To determine the light factors, the diurnal change in illumination was measured with a photoelectric cell and the solar radiation was simultaneously recorded using a Robitzsch pyrheliometer fixed on the deck. The submarine light illumination was estimated by means of a selenium photocell specially devised for submarine use. When direct photometry could not be available, the submarine light illumination was measured from the extinction coefficient of sea water using the formula $\alpha=1.7 / d$ (cf. Ryther 1958) where $\alpha$ is the extinction coefficient of sea water and $d$ is the SecchI disc reading. So far as our experimental data are concerned, the above formula proved to hold sufficiently good. For the examination of species composition of the phytoplankton, the net collection was made, the results of which will be reported elsewhere.

2. Chlorophyll content in the oceanic regions explored

The chlorophyll determination was made on 10-20 $l$ amount of water for Oyashio area and $40-60 l$, for Kuroshio area. The phytoplankton was filtered off by suction using four folded sheets of filterpaper (Toyo, No. 101: $9 \mathrm{~cm}$. in diameter), and its chlorophyll content was measured as pheophytin by means of colorimetric method described previously (Hogetsu and ICHImura, 1954). Photosynthesis was measured according to the ${ }^{14} \mathrm{C}$ method described by Steemann Nielsen, and the results obtained were corrected by substracting the dark fixation as was done by Dоту. The sample water was divided into four quarters; the two in transparent and the other two in dark bottles, respectively, and each of them was, after addition of ${ }^{14} \mathrm{C}$, immersed in an incubator of somewhat simplified Dоту's type during 3 to 6 hours. The
The chlorophyll measurement was carried out at 70 different stations. Some of the results are listed in Table 1 and the average values for euphotic layers are indicated in Fig. 2. Here, the euphotic layer is to be understood as such: its bottom lies at a level, where the submarine light intensity is reduced to 2-3 per cent of the surface value.

Recently, it was found by several investigators that phytoplankton shows a diurnal change in its chlorophyll content as well as photosynthetic activity. Furthermore, the change in photosynthetic activity occurs even under artificial illumination of the same intensity. According to some other experiments of the authors, however, the diurnal fluctuation in chlorophyll content was occasionally found to be 1.5-2.0 times as much with respect to the surface sample collected from 
Table 1. Chlorophyll content in the northwestern Pacific Ocean off Japan. Chlorophyll amount is expressed in mg. per cubic meter of sea water.

\begin{tabular}{|c|c|c|c|c|c|c|}
\hline \multicolumn{7}{|l|}{ August, 1957} \\
\hline $\begin{array}{l}\text { Station } \\
\text { Date } \\
\text { Trans. m. }\end{array}$ & $\begin{array}{c}31^{\circ} 35^{\prime} \mathrm{N} \\
136^{\circ} 56^{\prime} \mathrm{E} \\
\text { Aug. } 3 \\
29\end{array}$ & $\begin{array}{c}32^{\circ} 27^{\prime} \mathrm{N} \\
136^{\circ} 24^{\prime} \mathrm{E} \\
3 \\
30\end{array}$ & $\begin{array}{c}33^{\circ} 19^{\prime} \mathrm{N} \\
138^{\circ} 57^{\prime} \mathrm{E} \\
15 \\
-\end{array}$ & $\begin{array}{c}31^{\circ} 58^{\prime} \mathrm{N} \\
138^{\circ} 52^{\prime} \mathrm{N} \\
16 \\
36\end{array}$ & $\begin{array}{c}30^{\circ} 00^{\prime} \mathrm{N} \\
140^{\circ} 30^{\prime} \mathrm{E} \\
17 \\
33\end{array}$ & $\begin{array}{c}33^{\circ} 01^{\prime} \mathrm{N} \\
140^{\circ} 05^{\prime} \mathrm{E} \\
18 \\
27\end{array}$ \\
\hline $\begin{array}{c}\text { Depth m. } \\
0 \\
20 \\
50 \\
100\end{array}$ & $\begin{array}{l}0.09 \\
0.08 \\
0.24 \\
0.89\end{array}$ & $\begin{array}{l}0.08 \\
0.11 \\
0.10 \\
0.10\end{array}$ & $\begin{array}{l}0.13 \\
0.40 \\
0.49 \\
0.24\end{array}$ & $\begin{array}{l}0.12 \\
0.14 \\
0.19 \\
0.14\end{array}$ & $\begin{array}{l}0.21 \\
0.21 \\
0.16 \\
0.38\end{array}$ & $\begin{array}{l}0.19 \\
0.11 \\
0.28 \\
0.26\end{array}$ \\
\hline \multicolumn{7}{|l|}{ May, 1958} \\
\hline $\begin{array}{l}\text { Station } \\
\text { Date } \\
\text { Hour } \\
\text { Trans. m. }\end{array}$ & $\begin{array}{c}33^{\circ} 01^{\prime} \mathrm{N} \\
140^{\circ} 04^{\prime} \mathrm{E} \\
\text { May } 2 \\
1040 \\
17\end{array}$ & $\begin{array}{c}32^{\circ} 00^{\prime} \mathrm{N} \\
140^{\circ} 12^{\prime} \mathrm{E} \\
2 \\
1910 \\
20\end{array}$ & $\begin{array}{c}32^{\circ} 41^{\prime} \mathrm{N} \\
139^{\circ} 02^{\prime} \mathrm{E} \\
3 \\
0650 \\
23\end{array}$ & $\begin{array}{c}33^{\circ} 19^{\prime} \mathrm{N} \\
139^{\circ} 01^{\prime} \mathrm{E} \\
3 \\
1145 \\
21\end{array}$ & $\begin{array}{c}34^{\circ} 25^{\prime} \mathrm{N} \\
138^{\circ} 00^{\prime} \mathrm{E} \\
7 \\
1605 \\
12\end{array}$ & $\begin{array}{c}32^{\circ} 00^{\prime} \mathrm{N} \\
137^{\circ} 57^{\prime} \mathrm{E} \\
8 \\
1050 \\
20\end{array}$ \\
\hline $\begin{array}{c}\text { Depth m. } \\
0 \\
20 \\
50\end{array}$ & $\begin{array}{l}0.48 \\
0.45 \\
0.55\end{array}$ & $\begin{array}{l}0.42 \\
0.30 \\
0.32\end{array}$ & $\begin{array}{l}0.36 \\
0.21 \\
0.19\end{array}$ & $\begin{array}{l}0.26 \\
0.23 \\
-\end{array}$ & $\begin{array}{l}1.5 \\
1.6 \\
0.52\end{array}$ & $\begin{array}{l}0.24 \\
0.63 \\
0.63\end{array}$ \\
\hline \multicolumn{7}{|c|}{ July, August, 1958} \\
\hline $\begin{array}{l}\text { Station } \\
\text { Date } \\
\text { Hour } \\
\text { Trans. m. }\end{array}$ & $\begin{array}{c}29^{\circ} 56^{\prime} \mathrm{N} \\
145^{\circ} 03^{\prime} \mathrm{E} \\
\text { July } 27 \\
2130 \\
-\end{array}$ & $\begin{array}{c}35^{\circ} 58^{\prime} \mathrm{N} \\
145^{\circ} 03^{\prime} \mathrm{E} \\
30 \\
0752 \\
16\end{array}$ & $\begin{array}{c}38^{\circ} 00^{\prime} \mathrm{N} \\
145^{\circ} 00^{\prime} \mathrm{E} \\
31 \\
0204 \\
16\end{array}$ & $\begin{array}{r}38^{\circ} 15^{\prime} \mathrm{N} \\
149^{\circ} 56^{\prime} \mathrm{E} \\
\text { Aug. } 4 \\
0045 \\
-\end{array}$ & $\begin{array}{c}41^{\circ} 07^{\prime} \mathrm{N} \\
147^{\circ} 30^{\prime} \mathrm{E} \\
7 \\
1245 \\
7\end{array}$ & $\begin{array}{c}41^{\circ} 40^{\prime} \mathrm{N} \\
143^{\circ} 18^{\prime} \mathrm{E} \\
8 \\
1225 \\
9\end{array}$ \\
\hline $\begin{array}{c}\text { Depth m. } \\
0 \\
20 \\
50\end{array}$ & $\begin{array}{l}0.18 \\
0.14 \\
0.18\end{array}$ & $\begin{array}{l}0.35 \\
0.39 \\
0.33\end{array}$ & $\begin{array}{l}0.25 \\
0.48 \\
1.5\end{array}$ & $\begin{array}{l}0.28 \\
0.17 \\
0.24\end{array}$ & $\begin{array}{l}0.49 \\
0.88 \\
0.60\end{array}$ & $\begin{array}{l}0.77 \\
0.98 \\
1.2\end{array}$ \\
\hline \multicolumn{7}{|c|}{ August, September, 1958} \\
\hline $\begin{array}{l}\text { Station } \\
\text { Date } \\
\text { Hour } \\
\text { Trans. m. }\end{array}$ & $\begin{array}{r}48^{\circ} 04^{\prime} \mathrm{N} \\
165^{\circ} 11^{\prime} \mathrm{E} \\
\text { Aug. } 20 \\
1330 \\
9.5\end{array}$ & $\begin{array}{c}42^{\circ} 00^{\prime} \mathrm{N} \\
165^{\circ} 57^{\prime} \mathrm{E} \\
22 \\
1620 \\
13\end{array}$ & $\begin{array}{c}34^{\circ} 00^{\prime} \mathrm{N} \\
155^{\circ} 00^{\prime} \mathrm{E} \\
31 \\
1530 \\
27\end{array}$ & $\begin{array}{c}37^{\circ} 57^{\prime} \mathrm{N} \\
155^{\circ} 02^{\prime} \mathrm{E} \\
\text { Sept. } 2 \\
1210 \\
28\end{array}$ & $\begin{array}{r}43^{\circ} 58^{\prime} \mathrm{N} \\
154^{\circ} 55^{\prime} \mathrm{E} \\
5 \\
1430 \\
10\end{array}$ & $\begin{array}{r}47^{\circ} 58^{\prime} \mathrm{N} \\
154^{\circ} 56^{\prime} \mathrm{E} \\
7 \\
0430 \\
10\end{array}$ \\
\hline $\begin{array}{c}\text { Depth m. } \\
0 \\
10 \\
20 \\
30 \\
60\end{array}$ & $\begin{array}{l}0.61 \\
0.45 \\
0.41 \\
- \\
-\end{array}$ & $\begin{array}{l}0.26 \\
0.35 \\
0.38 \\
- \\
-\end{array}$ & $\begin{array}{l}0.14 \\
- \\
0.08 \\
0.11\end{array}$ & $\begin{array}{l}0.21 \\
- \\
\overline{0.15} \\
0.07\end{array}$ & $\begin{array}{l}0.65 \\
1.0 \\
1.4 \\
- \\
-\end{array}$ & $\begin{array}{l}0.59 \\
0.66 \\
- \\
- \\
-\end{array}$ \\
\hline
\end{tabular}

the sea areas so far explored. Under consideration of this fact together with the accuracy of the calculated value of daily production, the authors have made calculations by neglecting this minor fluctuation of chlorophyll content.
The chlorophyll stratification in the ocean was not so distinct as in the lake; however, a high concentration was sometimes observed in deeper layers, especially in a layer close to the thermocline for the Oyashio area, where the thermocline lies in the depths of 20-30 
meters and the Secchi disc readings are 7-15 meters. Therefore, the compensation depth agrees approximately with the thermocline. On the other hand, the nutrient condition was found to be almost uniform at least down to the bottom of the euphotic zone. From these results, it is surmised that the high chlorophyll concentration in deeper layers is brought about not by active growth of phytoplankton in these layers but chiefly precipitations of phytoplankton that has florished in upper layers.

As shown in Table 1 and Fig. 2 , remarkable difference in chlorophyll content exists between the two areas of Kuroshio and Oyashio. Average values were found as $0.5-0.7 \mathrm{mg} . / \mathrm{cu} . \mathrm{m}$ for the Oya-

Fig. 2. Chlorophyll content in the northwestern Pacific Ocean. Figures show the mean values of chlorophyll amount in the euphotic layer.
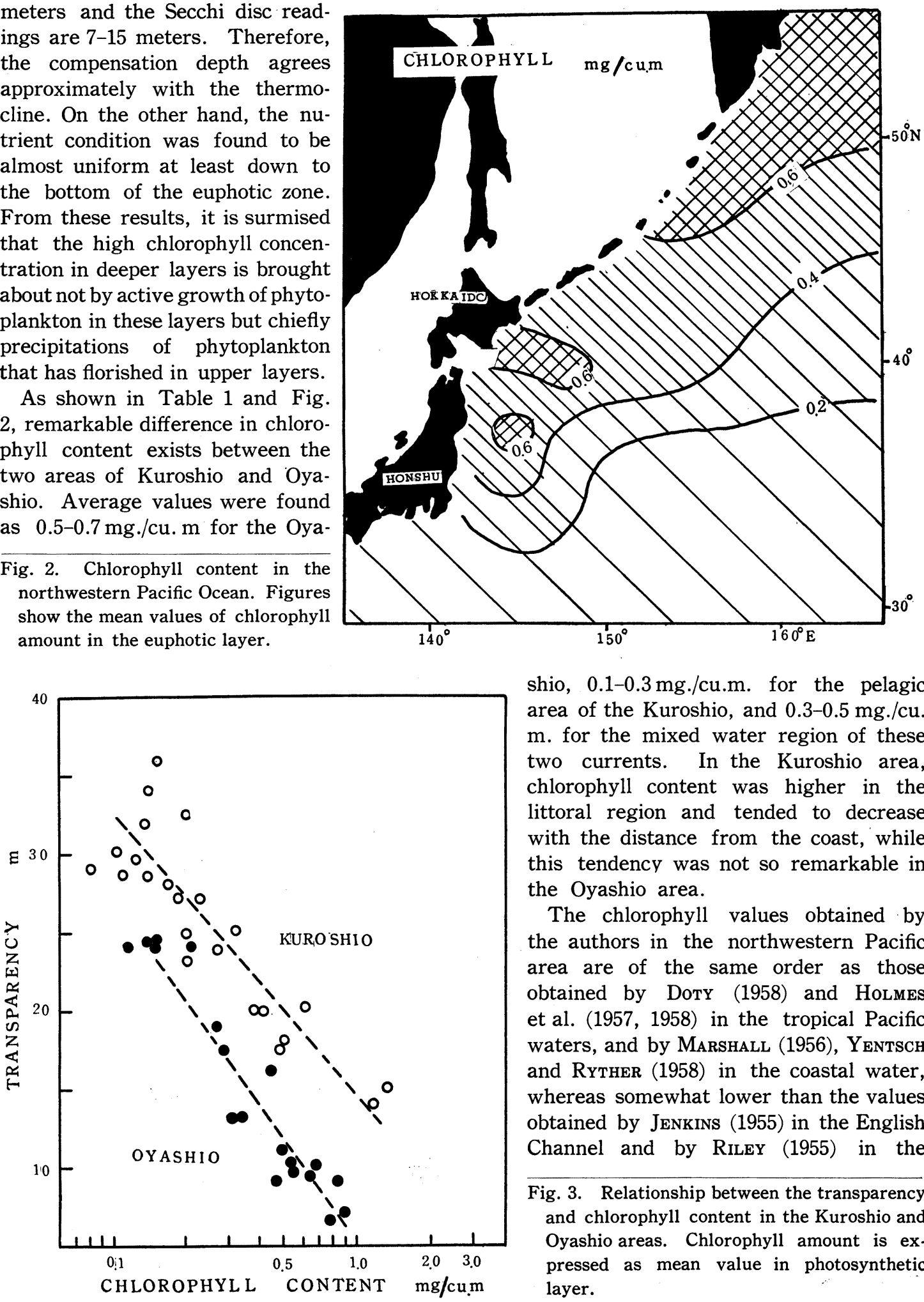

shio, $0.1-0.3 \mathrm{mg} . / \mathrm{cu} . \mathrm{m}$. for the pelagic area of the Kuroshio, and 0.3-0.5 mg./cu. $\mathrm{m}$. for the mixed water region of these two currents. In the Kuroshio area, chlorophyll content was higher in the littoral region and tended to decrease with the distance from the coast, while this tendency was not so remarkable in the Oyashio area.

The chlorophyll values obtained by the authors in the northwestern Pacific area are of the same order as those obtained by Dоту (1958) and HoLmes et al. $(1957,1958)$ in the tropical Pacific waters, and by Marshall (1956), YentsCH and RYTHER (1958) in the coastal water, whereas somewhat lower than the values obtained by JENkINs (1955) in the English Channel and by RILEY (1955) in the

Fig. 3. Relationship between the transparency and chlorophyll content in the Kuroshio and Oyashio areas. Chlorophyll amount is ex. pressed as mean value in photosynthetic layer. 
Long Island Sound waters.

Notable is the fact that in any of the oceanic regions examined linear relationship can be observed between the Secchi disc reading and the mean value of the chlorophyll content in the euphotic layer, and the difference between the two lines in Fig. 3 obtained as to the Oyashio and Kuroshio currents seems to indicate their difference in ratio of phytoplankton/zooplankton, being caused by a strong light absorption of rich zooplankton population in the Oyashio area.

\section{Photosynthetic rate of phytoplankton}

The photosynthetic rate was measured by the ${ }^{14} \mathrm{C}$ method under optimal light condition (15000 lux) and at surface water temperature. Since the temperature becomes lower with increasing depth in the sea, the samples taken from the deeper layers are expected to show somewhat greater photosynthetic rates in situ than those under the actual experimental conditions.

The data depicted in Table 2 are the values obtained under oversea conditions immediate-

Table 2. Productivity of sea water and photosynthetic rate of phytoplankton.

\begin{tabular}{|c|c|c|c|c|c|c|c|}
\hline \multirow[b]{2}{*}{ Stations } & \multirow[b]{2}{*}{ Hour } & \multirow[b]{2}{*}{ Date } & \multirow{2}{*}{$\begin{array}{l}\text { Depth of } \\
\text { sampling } \\
\text { in } \mathrm{m} .\end{array}$} & \multirow{2}{*}{$\begin{array}{l}\text { Water temp. } \\
\text { in situ } \\
{ }^{\circ} \mathrm{C}\end{array}$} & \multirow{2}{*}{$\begin{array}{l}\text { Experiment. } \\
\text { water temp. } \\
{ }^{\circ} \mathrm{C}\end{array}$} & \multicolumn{2}{|c|}{ Productivity } \\
\hline & & & & & & $\begin{array}{l}\mathrm{mg} . \mathrm{C} / \mathrm{hr} . \\
/ \mathrm{cu} . \mathrm{m} .\end{array}$ & $\begin{array}{l}\mathrm{mg} . \mathrm{C} / \mathrm{hr} . \\
\text { /chl. mg. }\end{array}$ \\
\hline $\begin{array}{r}33^{\circ} 01^{\prime} \mathrm{N} \\
140^{\circ} 04^{\prime} \mathrm{E}\end{array}$ & 0930 & May 2 & $\begin{array}{r}0 \\
20 \\
50\end{array}$ & $\begin{array}{l}20.5 \\
20.5 \\
20.5\end{array}$ & $\begin{array}{l}25 \\
25 \\
25\end{array}$ & $\begin{array}{l}0.62 \\
0.41 \\
0.36\end{array}$ & $\begin{array}{l}1.3 \\
0.91 \\
0.63\end{array}$ \\
\hline $\begin{array}{r}32^{\circ} 00^{\prime} \mathrm{N} \\
140^{\circ} 12^{\prime} \mathrm{E}\end{array}$ & 1810 & May 2 & $\begin{array}{l}20 \\
50\end{array}$ & $\begin{array}{l}20.5 \\
20.5\end{array}$ & $\begin{array}{l}25 \\
25\end{array}$ & $\begin{array}{l}0.20 \\
0.30\end{array}$ & $\begin{array}{l}0.67 \\
1.00\end{array}$ \\
\hline $\begin{array}{r}32^{\circ} 41^{\prime} \mathrm{N} \\
139^{\circ} 02^{\prime} \mathrm{E}\end{array}$ & 0600 & May 3 & $\begin{array}{r}0 \\
20 \\
50\end{array}$ & $\begin{array}{l}21.4 \\
21.6 \\
19.2\end{array}$ & $\begin{array}{l}25 \\
25 \\
25\end{array}$ & $\begin{array}{l}0.29 \\
0.07 \\
0.10\end{array}$ & $\begin{array}{l}0.66 \\
0.33 \\
0.53\end{array}$ \\
\hline $\begin{array}{r}34^{\circ} 00^{\prime} \mathrm{N} \\
139^{\circ} 01^{\prime} \mathrm{E}\end{array}$ & 1615 & May 3 & 0 & 19.2 & 23 & 2.2 & 1.7 \\
\hline $\begin{array}{r}34^{\circ} 25^{\prime} \mathrm{N} \\
138^{\circ} 00^{\prime} \mathrm{E}\end{array}$ & 1530 & May 7 & $\begin{array}{r}0 \\
20 \\
50\end{array}$ & $\begin{array}{l}19.2 \\
18.4 \\
18.1\end{array}$ & $\begin{array}{l}21 \\
21 \\
21\end{array}$ & $\begin{array}{l}2.4 \\
1.7 \\
0.77\end{array}$ & $\begin{array}{l}1.6 \\
1.1 \\
1.5\end{array}$ \\
\hline $\begin{array}{r}32^{\circ} 00^{\prime} \mathrm{N} \\
137^{\circ} 57^{\prime} \mathrm{E}\end{array}$ & 0955 & May 8 & $\begin{array}{r}0 \\
20 \\
50\end{array}$ & $\begin{array}{l}18.6 \\
18.5 \\
18.5\end{array}$ & $\begin{array}{l}21 \\
21 \\
21\end{array}$ & $\begin{array}{l}0.66 \\
1.5 \\
1.2\end{array}$ & $\begin{array}{l}2.5 \\
2.4 \\
1.8\end{array}$ \\
\hline $\begin{array}{r}33^{\circ} 00^{\prime} \mathrm{N} \\
135^{\circ} 41^{\prime} \mathrm{E}\end{array}$ & 0720 & May 9 & $\begin{array}{r}0 \\
20\end{array}$ & $\begin{array}{l}22.6 \\
22.8\end{array}$ & $\begin{array}{l}23 \\
23\end{array}$ & $\begin{array}{l}0.82 \\
0.69\end{array}$ & $\begin{array}{l}1.4 \\
1.3\end{array}$ \\
\hline $\begin{array}{r}33^{\circ} 25^{\prime}, \mathrm{E} \\
135^{\circ} 39^{\prime} \mathrm{E}\end{array}$ & 1115 & May 9 & 0 & 19.2 & 21 & 4.1 & 3.4 \\
\hline $\begin{array}{r}29^{\circ} 56^{\prime} \mathrm{N} \\
145^{\circ} 00^{\prime} \mathrm{E}\end{array}$ & 2130 & July 27 & $\begin{array}{r}0 \\
20 \\
50\end{array}$ & $\begin{array}{l}26.5 \\
25.1 \\
22.3\end{array}$ & $\begin{array}{l}26 \\
26 \\
26\end{array}$ & $\begin{array}{l}0.20 \\
0.24 \\
0.08\end{array}$ & $\begin{array}{l}1.1 \\
1.7 \\
0.45\end{array}$ \\
\hline $\begin{array}{r}32^{\circ} 00^{\prime} \mathrm{N} \\
145^{\circ} 00^{\prime} \mathrm{E}\end{array}$ & 1455 & July 28 & $\begin{array}{r}0 \\
20 \\
50\end{array}$ & $\begin{array}{l}26.3 \\
25.1 \\
21.7\end{array}$ & $\begin{array}{l}26 \\
26 \\
26\end{array}$ & $\begin{array}{l}0.24 \\
0.10 \\
0.08\end{array}$ & $\begin{array}{l}1.3 \\
1.0 \\
0.5\end{array}$ \\
\hline $\begin{array}{r}34^{\circ} 01^{\prime} \mathrm{N} \\
144^{\circ} 56^{\prime} \mathrm{E}\end{array}$ & 0858 & July 29 & $\begin{array}{r}0 \\
20 \\
50\end{array}$ & $\begin{array}{l}25.8 \\
22.7 \\
22.1\end{array}$ & $\begin{array}{l}25 \\
25 \\
25\end{array}$ & $\begin{array}{l}1.32 \\
0.44 \\
0.73\end{array}$ & $\begin{array}{l}2 . \overline{9} \\
2.2\end{array}$ \\
\hline $\begin{array}{r}41^{\circ} 59^{\prime} \mathrm{N} \\
145^{\circ} 06^{\prime} \mathrm{E}\end{array}$ & 1110 & Aug. 1 & $\begin{array}{r}0 \\
15 \\
30\end{array}$ & $\begin{array}{r}16.8 \\
15.5 \\
8.6\end{array}$ & $\begin{array}{l}16.8 \\
16.8 \\
16.8\end{array}$ & $\begin{array}{l}2.4 \\
2.0 \\
4.3\end{array}$ & $\begin{array}{l}5 . \overline{7} \\
4.3\end{array}$ \\
\hline $\begin{array}{r}42^{\circ} 27^{\prime} \mathrm{N} \\
148^{\circ} 56^{\prime} \mathrm{E}\end{array}$ & 1241 & Aug. 2 & $\begin{array}{r}0 \\
10 \\
30\end{array}$ & $\begin{array}{l}20.8 \\
20.7 \\
15.9\end{array}$ & $\begin{array}{l}20.8 \\
20.8 \\
20.8\end{array}$ & $\begin{array}{l}1.3 \\
1.3 \\
1.2\end{array}$ & $\begin{array}{l}2.9 \\
5.0 \\
4.3\end{array}$ \\
\hline $\begin{array}{r}41^{\circ} 07^{\prime} \mathrm{N} \\
147^{\circ} 36^{\prime} \mathrm{E}\end{array}$ & 1245 & Aug. 7 & $\begin{array}{r}0 \\
10 \\
20\end{array}$ & $\begin{array}{l}17.3 \\
13.4 \\
10.4\end{array}$ & $\begin{array}{l}17.3 \\
17.3 \\
17.3\end{array}$ & $\begin{array}{l}3.1 \\
2.5 \\
2.5\end{array}$ & $\begin{array}{l}6.4 \\
3.1 \\
2.8\end{array}$ \\
\hline
\end{tabular}


ly after sampling at various stations. The results show that the productivity of sea water is greater in both the Oyashio area and the littoral region of the Kuroshio than in the pelagic area of the Kuroshio current. The productivity in the Oyashio area is nearly equal to that in the littoral region of the Kuroshio area and in some cases the former is greater than the latter.

The productivity is $1-4 \mathrm{mg}$. C/cu. m./hr. in the Oyashio and in the littoral region of the Kuroshio, and $0.1-0.7 \mathrm{mg} . \mathrm{C} / \mathrm{cu} . \mathrm{m} . / \mathrm{hr}$. in the pelagic area of the Kuroshio. From these values, the photosynthetic rate per unit amount of chlorophyll is calculated as $3-6 \mathrm{mg}$. C/mg. $\mathrm{chl} . / \mathrm{hr}$. for the former two areas, and 0.3$0.7 \mathrm{mg}$. C/mg. chl. $/ \mathrm{hr}$. for the latter. The difference in photosynthetic rate between them resides chiefly in different nutrient conditions in these two areas, since the distribution of phosphate-P was found to be $0.2-0.4$ $\mu \mathrm{g}$. at./l. in the Oyashio area and $0.01-0.05$ $\mu \mathrm{g}$. at./l. in the Kuroshio area

The productivity in the northwestern Pacific is, in general, nearly equal to or somewhat lower than the previous values, i.e. $0.1-5.0 \mathrm{mg}$.C./cu.m./hr. measured by Doty (1956, 1958) and JitTs (1958) in the tropical Pacific and 0.1-4.0 mg. C./cu.m./hr. by Holmes $(1957,1958)$ in the eastern tropical Pacific.

As regards the potential photosynthetic activity per unit amount of phytoplankton, no significant difference is observed between various layers of the euphotic zone; rather lower values were sometimes encountered in several samples taken from the compensation depth or thermocline. This is probably due either to an inanimation of phytoplankton, or else may be due to the experimental conditions, in which measurement was made at a temperature higher than that in situ.

\section{Rate of primary production}

For the measurement of the primary production accurate conditions "in situ" could not be reproduced on the ship board. Therefore, the rate of production per square meter was estimated either by " tank" or "chlorophyll " method, as used by SteEmann Nielsen (1957) and Ryther and YeNtSCH (1957). In the present researches, the tank method was employed at several stations and the chlorophyll method at the other stations. For the calculation of the primary production in several, it is necessary to prepare a photosynthesis-light intensity curve fitted to each experimental station. But this way very difficult task on shipboard, so that the calculation of the primary production was made from RYtheR's figure (1956, p. 65, Fig. 2).

Under the optimal light condition usually applied in chlorophyll method, the mean value obtained was $3.7 \mathrm{mg}$. C/mg. chl. $/ \mathrm{hr}$. for the Oyashio current, $1.5 \mathrm{mg} . \mathrm{C} / \mathrm{mg}$. chl./hr. for the pelagic area of the Kuroshio, and 2.5 $\mathrm{mg}$. $\mathrm{C} / \mathrm{mg}$. chl./hr. for the mixed water region

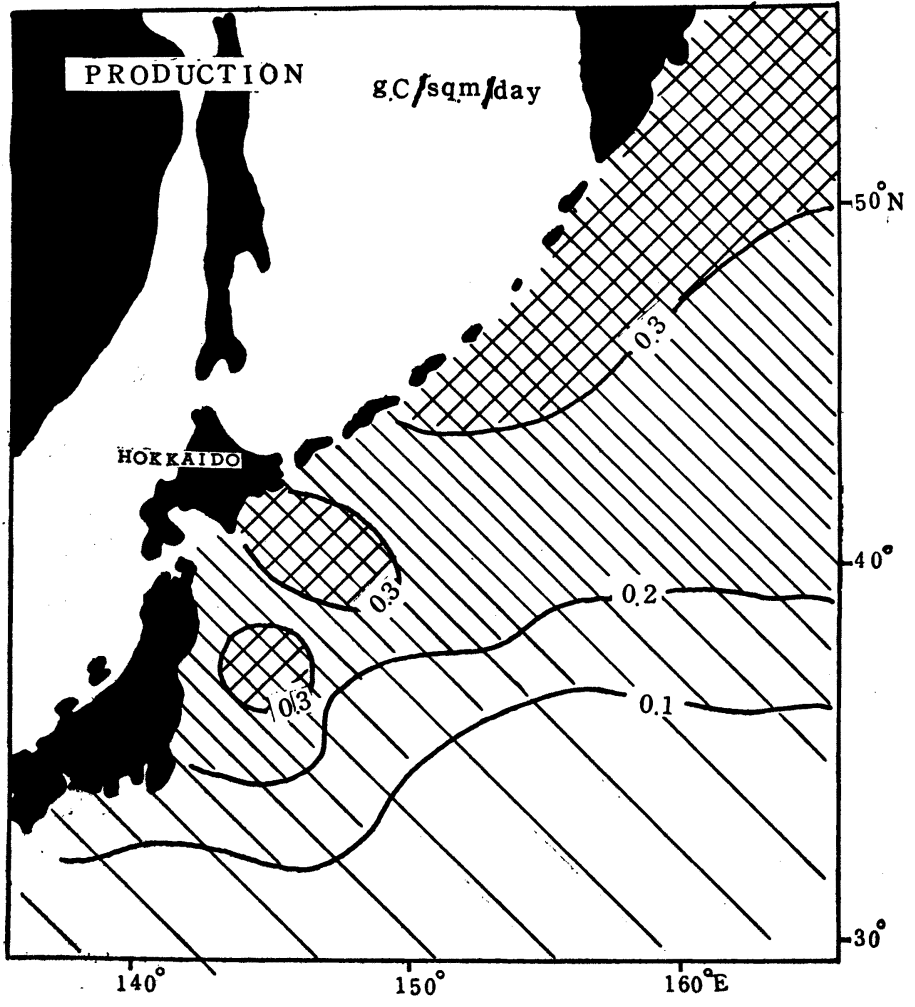

Fig. 4. Primary production in the northwestern Pacific Ocean. 
of these two currents. The daily primary productions calculated from these photosynthetic rates are illustrated in Fig. 4.

The rate of primary production was $0.2-$ $0.4 \mathrm{~g} . \mathrm{C} / \mathrm{sq} . \mathrm{m} . /$ day for the Oyashio area, $0.05-0.1 \mathrm{~g} . \mathrm{C} / \mathrm{sq} . \mathrm{m} . / \mathrm{day}$ for the mixed water region. In the littoral regions of the Oyashio and Kuroshio currents were obtained the high production values that exceed even the value $1 \mathrm{~g} . \mathrm{C} / \mathrm{sq} . \mathrm{m} . /$ day in some cases. Besides, it is noteworthy that the values fall approximately on the same line with those reported by Steemann Nielsen in the middle Pacific area but not with some of the values described by SoRokIn (1958) for the seas of Hokkaido.

The authors wish to express their thanks to Dr. J. Masuzawa, Mr. M. Ohwada, Mr. A. AsAoka and other staffs of the Marine Division, Japan Meteorological Agency for their kind support for the said researches.

The authors also wish to extend their cordial gratitude to Prof. K. Sugawara, Prof. M. Monsi and Prof. K. Hogetsu who gave helpful suggestions and valuable advice.

\section{References}

1. DotY, M. S. and OGuRI, M. 1956: The island mass effect. Jour. du Cons., 22:33.

2. DотY, M. S. 1958: Current status of carbonfourteen method of assaying productivity of the ocean. University of Hawaii.

3. HogetSU, K. and ICHImURA, S. 1954: Studies on the biological production of lake Suwa. VI. The ecological studies on the production of phytoplankton. Jap. Jour. Bot. 14:280.

4. Holmes, R. W., Schaefer, M. B. and ShimaDA, B. M. 1957: Primary production, chlorophyll, and zooplankton volumes in the tropical Eastern Pacific Ocean. Bulletin of the InterAmerican Tropical Tuna Commission, 2:129.
5. Holmes, R. W. 1958: Physical, chemical, and biological oceanographic observations obtained on expedition SCOPE in the Eastern Tropical Pacific November-December 1956: United States Department of the Interior Fish and Wildlife Service. Special Science Report-Fisheries No. 279.

6. Jenkins, P. G. 1955: Seasonal changes in the phytoplankton as indicated by spectrophotometric chlorophyll estimations 1952-1953. Papers in Marine Biology and Oceanography: 58.

7. JitTs, H. R. and RotsChI, H. 1958: Mesure par la methode au ${ }^{14} \mathrm{C}$ de l'activite photosynthetique de quelques masses d'eau du Pacifique Sud-Ouest en relation avec l'etude de la fertilite de ces meses eaux. Radioisotopes in Scientific Research (Proceeding of the 1st (UNESCO) International Conference) $4: 607$.

8. MARShall, N. 1956: Chlorophyll a in the phytoplankton in coastal waters of the eastern Gulf of Mexico. Jour. Mar. Res., 15:14.

9. MIYAKE, Y. 1958: A study on the organic productivity and the solubility product of $\mathrm{CaCO}_{3}$ in the ocean by means of the radiocarbon $\mathrm{C}^{14}$. Radioisotopes in Scientific Research (Proceedings of the 1st (UNESCO) International Conference) $4: 651$.

10. RILEY, G. A. 1955: Review of the oceanography of Long Island Sound. Paper in Marine Biology and Oceanography: 224.

11. RYtheR J. H. 1956: Photosynthesis in the ocean as a function of light intensity. Limnology and Oceanography 1:61.

12. SoRoKIN, J. I. 1958: The results and prospects of using carbon-14 for study of organic matter cycle in water basins. Radioisotopes in Scientific Research (Proceeding of the 1st (UNESCO) International Conference) $4: 633$.

13. Steemann Nielsen, E., and Jensen, E. AABYE, 1957: Primary oceanic production. The autotrophic production of organic matter in the ocean. Galathea Rep., 49. 